\title{
CAVEAT MEDICUS: PRACTISING WITH ANOTHER DENTIST MAY BE HAZARDOUS TO YOUR FINANCIAL HEALTH
}

\author{
GERALD D. CHIPEUR'
}

The author reviews recent decisions on the ownership of patient medical records when a dental practice splits. Firstly: he notes the fiducian. relationship physicians have to their patients in regards to medical records such that among doctor and patient the doctor owns such records only for the benefit of the patient. He goves on to explain how: ownership among medical practitioners depends on whether their relutionship is one of partnership. employment, or independent contractor. This analysis can be further complicated by factors like restrictive covenants and the need to be reasonable. Finally he notes the importance of well written agreements (o) help dentists avoid complicated and expensive litigation by providing solutions for such problems before they occur.
L'auteur examine les récentes décisions concernant la propriété du dossier médical du patien quand les partenaires d'un cabinet de dentistes se séparent. Premièrement, il note la relation de confiance qui existe à cet égard entre le patient et le médecin. et en vertu de laquelle le médecin agit dans l'intérêt du patiem. Il explique ensuite comment, dans un cabinet réunissant plusieurs dentistes, la notion de propriété depend de la nature de l'entente conclue entre les interessés partenariat, emploi. pratique indépendante. Cette analyse peut être compliquép par d'autres facteurs clauses restrictives at nécessité d'être raisonnable, par exemple. Finalement. l'auteur note l'importance de conclure des ententes soigneusement fornulées afin d'éviter les. litiges compliqués el onéreux et d'offrir des solutions. avam la sunienue de tels problèmes.

\section{TABLE OF CONTENTS}

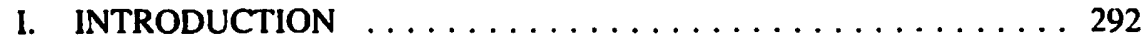

1I. WHO OWNS THE CHART? . . . . . . . . . . . . . 293

111. EMPLOYEE OR INDEPENDENT CONTRACTOR? . . . . . . . 294

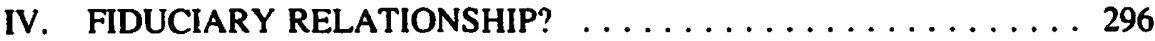

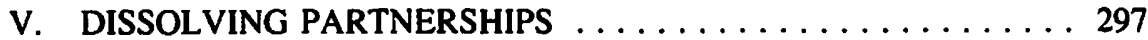

VI. RESTRICTIVE COVENANTS $\ldots \ldots \ldots \ldots \ldots \ldots \ldots \ldots \ldots 298$

VII. ACTING REASONABLY . . . . . . . . . . . . . . . . . 299

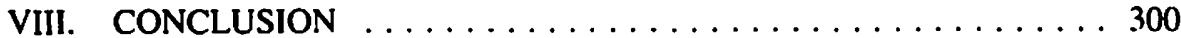

\section{INTRODUCTION}

What would you advise if a dentist client called to tell you that:

1. he is on his way to the airport for a three week vacation in the Virgin Islands and his popular young associate has just announced that he is leaving the office to establish a practice across the street;

2. he is golfing with his employer and she has just told him that his services as a dentist in her office are no longer required; or

3. she has just administered local anaesthetic to a patient and her partner has handed her a notice of dissolution under their partnership agreement? 
Your advice should be obvious:

1. Arrive at the airport at least 90 minutes before your flight as you have an international destination;

2. Keep your eye on the ball and follow through on your swing; and

3. Wait for the aesthetic to take effect before commencing the procedure.

For many dentists, however, the answers have not been so obvious. During the past few years a surprising number of dentists have paid large fees to lawyers for the privilege of asking a judge to answer questions such as these. However, even before the lawsuits fly, the most common response of dentists to the dissolution of professional working relationships is to grab the patient records before the other dentist. In fact, it is because of this "possessiveness" with respect to patient records that disputes involving the dissolution of dental practice groups often end up in court.

This article will review recent Canadian court decisions on the ownership of patient records and identify the legal principles which determine who will walk away with the charts when dentists no longer practice together.

\section{WHO OWNS THE CHART?}

In discussing patient records it is first important to clarify the relationship between the patient and the dentist. No one would make the argument that a dentist or other health care professional could own a patient. However, it is generally accepted that a health care professional may own a patient's record.' In the past, patients have had very limited, if any, right of access to their own health information. The current trend, though, is to allow patients complete access to the information on their charts or health care files.

Recently, the Supreme Court of Canada put the force of the common law behind the access movement in the case of McInerney v. MacDonald. 'This case involved a patient's application for access to medical charts maintained by a physician, Dr. McInerney, together with all the consultants' reports and records of other physicians that were a) related to the patient; and, b) in the possession of Dr. Mclnerney. The Supreme Court concluded that patients must generally have access to all information on their charts. It noted that we live in a mobile society with a growing need to be fully informed about our health care. Access to information is essential if a patient is to make an informed decision when choosing a health care provider or determining the appropriate form of treatment. It is also important to the relationship of trust between caregiver and patient. It is on this principle that the court grounded its decision. A doctor is under a fiduciary duty to 
provide access to a patient's own records. The doctor only holds the information for the "beneficial interest" of the patient. ${ }^{3}$

While it is clear that the dentist owns the dental charts, it is not always clear which dentist owns a particular patient chart, particularly in a multi-dentist practice. Under the common law, and in the absence of an agreement to the contrary, the owner of the dental practice owns all the patient records. Thus, it becomes critical to determine who owns the practice. To answer this question in the context of a given practice situation, it will be necessary to analyze the relationship between the dentists in the group. Is it one of partnership, employment or independent contract? In a partnership, the agreement between the partners will govern. Usually patient charts are a partnership asset. If an employment relationship exists, patient charts will belong to the employer unless the employment contract provides otherwise. If the dentists are independent contractors, then they will each own the charts of their respective patients.

There is little difficulty determining whether or not a partnership exists. Most litigation involving dental partnerships does not involve this question. More often, partnership disputes centre around the question of whether a particular asset is a partnership asset and the question of how and when the partnership should be dissolved. These questions will be addressed later in this article. A more difficult question for the courts is the distinction between contracts of service (employment agreements) and contracts for services (independent contracts).

\section{EMPLOYEE OR INDEPENDENT CONTRACTOR?}

The difference between independent contractors and employees was explained in the judgment of Justice Saunders of the Ontario High Court of Justice in Bacher v. Obar. ${ }^{4}$ Both Dr. Bacher and Dr. Obar were dentists. They worked together for $4 \frac{1}{2}$ years without a written agreement in place. Dr. Bacher's management corporation managed the practice of both dentists. Dr. Obar paid 45 percent of the first $\$ 100,000$ of gross billings and 40 percent of any excess to the management corporation. After the two had worked together for some time, Dr. Bacher presented Dr. Obar with a partnership proposal. After discussing it with his advisers, Dr. Obar decided that he would be better off on his own. Without telling Dr. Bacher, Dr. Obar leased new premises across the street and started copying his patients' charts. When Dr. Bacher discovered this, he asked Dr. Obar to leave. Dr. Obar did so and opened his new office across the street a few days later. Dr. Obar sent out announcement cards to his patients and telephoned some patients who had appointments with him at his old office. Dr. Bacher responded by keeping Dr. Obar's name on the sign outside his office for nearly a year after Dr. Obar left, and misinforming some patients about Dr. Obar's new location.

The relationship between the dentists for most of their $4 \frac{1}{2}$ years together was "to the mutual advantage of each of them and to the advantage of the community as a whole."

Ibid. at 744.

Bacher v. Obar (1989), 28 C.C.E.L. 160 (Ont. H.C.).

Ibid. at 174. 
It was only toward the end of this period that acrimony developed. In the words of the judge. the relationship "had evolved to the point where the time was ripe. if not over ripe. for it to change or terminate."

Unfortunately, the close relationship between the dentists did not survive the termination of their practice together. Under the stress of the break up of their business relationship the conduct of both parties was "less than admirable."7 The relationship eventually deteriorated to the point where litigation was initiated. Dr. Bacher sued Dr. Obar for operating a dental practice within a one mile radius of Dr. Bacher's office, for misusing patient records and for soliciting Dr. Bacher's patients. Dr. Obar counterclaimed for damages flowing from his termination and Dr. Bacher's subsequent actions.

Justice Saunders first had to determine who owned the patient charts or records. There was no written contract between the dentists. Dr. Obar would own them if he was an independent contractor, while Dr. Bacher would own them if an employment relationship existed. In his judgment, Justice Saunders identified several factors consistent with the existence of either conclusion. However, he thought that the issue was conclusively determined by the financial arrangements between the parties. For income tax purposes. Dr. Obar was not treated as an employee of Dr. Bacher, but as a cost sharer through a contractual relationship with Dr. Bacher's management corporation. There was no direct contractual relationship between the dentists: Dr. Obar paid the management corporation, not Dr. Bacher, a percentage of his fees. Because the management corporation could not practice dentistry, it could not employ Dr. Obar as a dentist. Justice Saunders concluded that it indeed did not do so and gave this note of waming to dentists:"

\footnotetext{
The usc of management corpurations by dentists and other prolissionals is well-established. The purpose of their creation is the reduction of tax payable personally by the professionals. Over the years, recognized guidelines have developed between the professionals and the revenue authorily. Taxpaycrs may arrange their affairs in such a way as to minimize the elfect of taxation. If they do so. they must accept the legal consequences of what they have donc.
}

Notwithstanding that the dentists were independent contractors and that there was no written contract. Justice Saunders held that they nonetheless "had a duty to act reasonably toward the other in conducting their affairs." $\mathrm{He}$ concluded that neither dentist completely lived up to that duty. Accordingly, he awarded damages against Dr. Obar for the loss suffered by Dr. Bacher's management corporation when Dr. Obar quit without reasonable notice. Those damages were set at six weeks net revenues of the management corporation. Damages were also awarded against Dr. Bacher for the loss of business suffered by Dr. Obar when Dr. Bacher misled members of the public as to the existence or location of Dr. Obar's practice. The value of the loss was set at $\$ 4,600$. Dr. Bacher

Ibid.

Ibid. al 176.

Ubid. at 171. Justice Saunders did not follow the approach ol the Newfoundland District Coun in Peters v. Pulmer (1985), 156 A.P.R. 152 where the Court found a similar arrangement to be one of convenience. a device lor persional tax advantage only, and not to be a weighty or influential factor. 
was also ordered to pay $\$ 680.00$ for failing to comply with Dr. Obar's request for $x$-rays on a timely basis. In the end, the claims largely cancelled each other out.

In Dangstorp v. Lefebvre," Justice Hunter of the Saskatchewan Court of Queen's Bench applied Bacher v. Obar in dismissing an interlocutory injunction application by a senior dentist, Dr. Dangstorp, who wished to have a former associate, Dr. Lefebvre, enjoined from contacting former patients and from opening a competing office in the same shopping mall as the senior dentist. After practising together for one year, Dr. Dangstorp terminated the relationship Dr. Lefebvre had with him and his partner. Dr. Lefebvre then decided to set up a new office in the same shopping mall as her previous office with Dr. Dangstorp. She also contacted previous patients and advertised her new office in the local newspaper.

As there was no written contract in place between the dentists, there were no contractual undertakings or restrictive covenants to prevent $\mathrm{Dr}$. Lefebvre from competing with Dr. Dangstorp in this way. Furthermore, Justice Hunter said that it was not clear whether Dr. Lefebvre was an associate or an employee. Therefore, the only basis for an injunction would have been the existence of a fiduciary duty between the dentists. However, Justice Hunter was not satisfied that the junior dentist owed the senior dentist a fiduciary duty or that she was in breach of such duty if it existed." In arriving at this conclusion, she noted that Bacher v. Obar supported the proposition "that professionals do not have a proprietary right from the office to facilitate proper treatment of the patients." 12

Similar litigation is currently ongoing in Edmonton. The case is Mah v. Birzgulis. ${ }^{13}$ Like Dr. Obar and Dr. Bacher, Dr. Mah and Dr. Birzgalis had no written contract. After Dr. Birzgalis terminated their relationship without notice, each dentist commenced action against the other. ${ }^{14}$ Prior to trial, Justice A. T. Murray granted an interlocutory injunction in favour of the junior dentist, Dr. Mah, giving him possession of the charts relating to his patients. ${ }^{15}$ The order also prohibited the senior practitioner, Dr. Birzgalis, from soliciting the patients of Dr. Mah. In addition, Dr. Mah was restricted to mailing one announcement of the new location of his practice, without further soliciting his patients. In making this order, Justice Murray sought to maintain the status quo until trial.

\section{FIDUCIARY RELATIONSHIP?}

Even when there are written agreements in place, things can go wrong. Such was the case in Kronick v. Lamarche. ${ }^{16}$ In 1984, Dr. Kronick sold his dental practice to Dr. Lamarche. At the time he was thinking of retiring, but agreed to stay on with Dr.

11 Dangstoup v. Lefebire (1992), 43 C.P.R. (3rd) 469 (Sask. Q.B.).

Ibid. at 472.

lbid.

Mah v. Birzgulis. Q.B. Action No. 9203-24141, filed Nov. 26, 1992.

Birzgatis v. Mah. Q.B. Action No. 9203-24097, filed Nov. 26, 1992.

Mah v. Birsgalis, supra note 13.

Kronick v. Lamurche. Action No. 312341/88 (Ont. Gen. Div. May 21, 1991). 
Lamarche as an associate for one year. The sale agreement included a clause prohibiting Dr. Kronick from practicing dentistry within five miles of his former practice for a period of three years.

Dr. Kronick eventually stayed on with Dr. Lamarche until June 1987, a little more than three years after the sale. In June 1987, Dr. Kronick set up a practice in competition with Dr. Lamarche within the five mile radius prohibited by the sale agreement and notified his patients of the move. However, as the three year limitation had expired, Dr. Lamarche could not maintain an action for breach of the restrictive covenant.

Dr. Lamarche did have another potential claim against Dr. Kronick which required adjudication. She alleged that Dr. Kronick had misused or stolen confidential patient information or had breached his fiduciary duty to her by notifying his patients of his move. However, the Court rejected this claim on the basis that no fiduciary duty existed and that there was no property in a patient. ${ }^{17}$ On this issue, the Court quoted with approval the Ontario High Court of Justice decision in Goodman v. Newman: ${ }^{18}$

|P|rofessionals. such as dectors, dentists and lawyers do not have the same proprietary right to their patients or clients as Joes a corporation to its customers. Professionals provide a personal service and establish a personal relationship with their clients, regardless of where or how the client or patient arrived at the firm or practice. The client or patient ought not to be 'handcuffed' to the business.

In Goodman v. Newman, Dr. Goodman had employed Dr. Newman for some ten years as a dentist in his practice. Over a period of several years the possibility of partnership was discussed. In the final analysis, no partnership was agreed upon, and Dr. Newman left Dr. Goodman's practice. When Dr. Newman left, he took with him a list of six hundred patients he had personally served. Dr. Goodman asked the Ontario High Court of Justice for an injunction to prevent Dr. Newman from using the list of six hundred patients on the basis that such information was confidential and belonged to the practice. The court disagreed; it held that the patient list did not constitute confidential information and dismissed the injunction application.

\section{DISSOLVING PARTNERSHIPS}

Two recent decisions of the Ontario Court of Justice illustrate that partnership agreements are also prone to conflict, particularly at the time of dissolution. In Kamin v. $K_{e l l e n^{19}}$ the issue was whether the partnership agreement allowed departing partners to both demand payment for their "goodwill" in the partnership and take patient records or

Ihid.

This conclusion is at odds with the decision of the British Columbia County Court in Anderson v. Nelford. Van. Reg. No. F880240 (B.C. Co. Ct. Nov. 17. 1989) where the relationship between a law firm and an associate lawyer was held to be fiduciary in nature. However, notwithstanding this conclusion. the County Cour held that the associatc lawyer had the right and duty to advise his clients when he left the firm and let them know that they had a choice to stay with the firm or go with him. The Courn noted that "there is a way of taking a business advantage which breaches one's fiduciary duty, and a way which does non."

Kamin v. Kell'n (1986), 13 C.P.R. (3d) 48 (Ont. H.C.) aff'd. C.A. No. 695/86 (Mar. 25, 1988). 
charts when they left. The Court said no. The partnership agreement was ambiguous, but, based on testimony from the parties, the judge concluded that a former partner could not have his cake and eat it too.

In Kucher v. Moore," Dr. Kucher had a different problem. Dr. Moore, his partner of thirteen years, was found guilty by the Dental College of overcharging and poor recordkeeping and consequently was suspended for nine months. In addition to the suspension, Dr. Moore was away from the practice for medical reasons and received disability insurance for an extended period of time. Because of these problems, Dr. Kucher tried to negotiate a dissolution of the partnership in 1986. The two dentists did not reach an agreement concerming the termination of the partnership and litigation eventually ensued. The trial addressed two key questions. Firstly, did the partnership terminate in 1986? Secondly, was the property housing the dental practice a partnership asset? Both questions were important because the property had increased in value from $\$ 446,125$ in 1986 to $\$ 1,180,000$ in 1990 . If the partnership did not terminate, or if the dentists owned the property outside of the partnership, then Dr. Kucher would owe Dr. Moore half of $\$ 1,180,000$ rather than half of $\$ 446,125$.

The Ontario Court of Justice first determined that the property was a partnership asset and then proceeded to ascertain whether the partnership had been dissolved in 1986. The Court accepted Dr. Moore's testimony that he had never agreed to the termination of the partnership in 1986. The Court nonetheless held that the partnership ended in 1986. The Court concluded, because of misconduct on the part of Dr. Moore, that it would be just and equitable to have the partnership dissolved as of 1986. Dr. Moore's misconduct involved a ploy on his part to deceive Dr. Kucher with respect to the amount of money he was receiving from the disability insurance company. Dr. Moore surreptitiously obtained some letterhead from the insurance company and hired an independent typist to make up a letter indicating that the disability insurance payments had been $\$ 19,000$ rather than the actual amount which was five times as much. Dr. Moore had the typist sign the letter as an employee of the insurance company and the letter was then given to Dr. Kucher. The Court found that this deceit entitled Dr. Kucher to treat the partnership as being at an end.

\section{RESTRICTIVE COVENANTS}

The lesson to be learned from the less than friendly parting of the ways between some of the dentists referred to in this article is that a well structured written agreement, including restrictive covenants, should be in place before a group of two or more dentists commence working together. This is particularly important for senior dentists with established practices. In the absence of an agreement governing such issues as ownership of patient records and noncompetition, the common law favours the junior dentist. The law places few restrictions on the use of patient records or on competition where dentists are independent contractors. Even where an employment relationship exists, the senior practitioner is not fully protected. While the junior dentist cannot take patient records 
when he or she leaves the practice, there is no restriction against setting up a new practice next door and advising patients of the move.

Established practitioners should ensure that the appropriate restrictive covenants are in place when they start to practice with other dentists, regardless of whether the relationship is one of partnership, employment or independent contract. Restrictive covenants can be placed in partnership agreements, employment agreements and independent contracts. In addition, depending upon the circumstances, established dentists may also secure protection by negotiating restrictive covenants in unanimous shareholder agreements or shopping centre leases.

\section{ACTING REASONABLY}

In the endeavour to protect oneself from unfair competition, a dentist should not lose sight of the reason for the presence of restrictive covenants in the first place; that is, to enhance the value of a practice. There may be times when the close proximity of other dentists helps rather than hinders a practice.

The case of Gray v. J.N.S. Developments Lid." illustrates the folly of enforcing a restrictive covenant like wearing "blinders." Dr. Gray had carried on the practice of dentistry since 1987 in a shopping centre operated by J.N.S. Developments. The lease provided that J.N.S. Developments would not lease other premises in the shopping centre for the use of another dentist. J.N.S. Developments developed a second phase to the shopping centre in 1988, and in 1990 agreed to lease area in the second phase to a dental surgeon by the name of Dr. Stranks. When Dr. Gray learned of the agreement he commenced legal action and asked the Ontario High Court of Justice to issue an injunction preventing Dr. Stranks from moving into the shopping centre pending trial. However, the Court could not think of any damage Dr. Gray would suffer from the presence of Dr. Stranks' practice in the same shopping centre. In fact, the evidence was that Dr. Gray would actually benefit from such presence. The Court noted that the practices of the two dentists were very different in nature. Dr. Gray relied heavily upon a walk-in practice. Dr. Stranks, on the other hand, was a specialist with very few walk-in patients. Almost all of Dr. Stranks' practice was by way of referral. The evidence even disclosed that Dr. Gray referred patients to Dr. Stranks. Notwithstanding the difference between their practices and the fact that Dr. Gray admitted in cross-examination that he was unable to indicate what damages he would suffer if Dr. Stranks were to move into the shopping centre, Dr. Gray insisted on enforcing the restrictive covenant. Dr. Gray even rejected an offer by Dr. Stranks "to keep accurate record of all patients as to where they have been referred from and not to take any walk-in patients but to refer them all to Dr. Gray."22

After reviewing the legal principles governing the granting of an injunction, the Ontario High Court of Justice refused to enjoin Dr. Stranks from opening up his practice in the

$=\quad$ Gra. v. J.N.S. Developments Lud. Action No. $45534 / 90$ (Ont. H.C. Mar. 12, 1990). 
same shopping centre as Dr. Gray. ${ }^{23}$ The main reason for refusing to grant such an injunction was the Court's belief that Dr. Gray would not suffer irreparable damage, an essential precondition to an injunction. In fact, the Court thought that the presence of Dr. Stranks would attract more people to the shopping centre, secking dental services from Dr. Gray.

\section{CONCLUSION}

If care is taken to have a written agreement in place before dentists start practicing together, the legal answers to the questions posed at the beginning of this article will not be hard to discern. A well drafted partnership, employment or independent contract will anticipate potential controversies and provide explicit answers so that the parties do not need to ask the courts for help. Dentists in group practice should insist on a written agreement, tailored to their situation, which covers the potential problems identified in this article. 